\title{
Detection of Chlamydophila psittaci in chickens by complement fixation test and polymerase chain reaction
}

\author{
Wafaa A. Osman*, A. L. El-Naggar, Azza S. A. Gooda, Mona A. Mahmoud \\ Animal Health Department, Desert Research Center, Cairo, Egypt.
}

\begin{abstract}
This study was carried out on 68 randomly collected chickens located at Ras Sedr Research Station, Desert Research Center, 68 serum samples were examined serologically by complement fixation test (CFT). Twenty out of $68(29.91 \%)$ had antibodies against Chlamydophila psittaci. Ten blood samples of the serologically positive cases were subjected to polymerase chain reaction (PCR) and showed positive results for Chlamydophila psittaci at $119 \mathrm{bp}$. Therefore PCR was found to be reliable, rapid, sensitive and specific technique for the detection Chlamydophila psittaci in birds. Serologically positive birds did not show any clinical symptoms of disease, but they were in contact with sheep and goat that showed previous abortion and were positive for $C$. abortus. It is recommended to avoid breeding of chickens with other animal species in the same yard because chickens become asymptomatic carrier with shedding of Chlamydophila psittaci in their feaces and respiratory discharges.
\end{abstract}

Chlamydia, are obligate intracellular parasites causing a variety of infections in animals and birds as well as respiratory, genital, digestive and ocular infections in human (Duan et al., 1999; Ketz and Carpenter, 1999). Chlamydiosis is a very important infectious disease in more than 469 different bird species (Kaleta and Taday, 2003). In addition chlamydial infections have also been reported in mammals, reptiles and amphibians (Eugster, 1980; Wilcke et al., 1983; Vanrompay et al., 1994).

Everett et al. (1999) proposed a new classification of chlamydia into two genera and nine species, based primarily on ribosomal RNA sequence, also chlamydiosis in birds, has been recently renamed chlamydophilosis.

The organism is shed in the feces and respiratory secretions of infected birds which play an important role in the transmission of infection. Other birds pick up the organism by inhaling contaminated aerosol. Although infected birds may become extremely ill and die, most birds usually become asymptomatic carriers and they act as source of infection. Without specific test, it is difficult to differentiate negative from positive psittacosis

\footnotetext{
* Corresponding author. Tel.: +20 26369132; fax: +2026387808 .

E-mail address: wosman_vet@yahoo.com (Wafaa A. Osman).
}

carrier (Eugster, 1980).

Serological diagnosis of chlamydial infection in birds can be based on serological evidence coupled with isolation of the etiological agent (Chahota et al., 1997).

The diagnosis of Chlamydia psittaci infection in birds often requires a multiple test approach in order to assure the most accurate results (Grimes, 1984, 1985; Grimes and Arizmendi, 1990 and Tully, 1991).

In previous studies, using complement fixation test, the presence of Chlamydophila spp. in pigeons was confirmed by (Greguric et al., 1989; Vlahovic, et al., 1998; Pavak et al., 2000) as they reported that $43.88 \%, 40.9 \%$ and $47.70 \%$ of pigeons were positive for C. psittaci antibodies respectively.

Vlahovic et al. (1998), Dottori et al. (2000), Guscetti et al. (2000), Kemf et al. (2000) and Travnicek et al. (2000) used complement fixation test to detect antibodies against chlamydia in avian sera.

Due to cross reactivity between Chlamydophila species the CFT is not specific and polymerase chain reaction (PCR) assays can be used to distinguish C. psittaci infection from infection with other Chlamydophila species (Messmer et al., 1997).

The aim of this study was to conduct serodiagnostic studies on sera of chickens by complement fixation test and polymerase chain reaction $(\mathrm{PCR})$. 

Table (1): The master mix ingredients and primers concentration used in PCR.

\begin{tabular}{lcccc}
\hline \multicolumn{1}{c}{ Constituent } & $\begin{array}{c}\text { Initial } \\
\text { concentration }\end{array}$ & Amount $(\mu \mathrm{l})$ & $\begin{array}{c}\text { Final } \\
\text { concentration }\end{array}$ & $\mathbf{x}^{\mathbf{8}}$ \\
\hline Distilled water & & 13.2 & & $105.6 \mu \mathrm{l}$ \\
Buffer & $10 \mathrm{x}$ & 2.0 & & $16.0 \mu \mathrm{l}$ \\
dNTP & $10 \mathrm{mM}$ & 0.4 & $0.2 \mathrm{mM}$ & $3.2 \mu \mathrm{l}$ \\
Taq polymerase & $5 \mu / \mathrm{Ml}$ & 0.4 & $2 \mu / \mathrm{Ml}$ & $3.2 \mu \mathrm{l}$ \\
Primer 2AF & $20 \mathrm{mM}$ & 1.0 & $1 \mathrm{mM}$ & $8.0 \mu \mathrm{l}$ \\
Primer 2Br & $20 \mathrm{mM}$ & 1.0 & $1 \mathrm{mM}$ & $8.0 \mu \mathrm{l}$ \\
$\quad$ Total volume & & $18.0 \mu \mathrm{l}$ & & $144.0 \mu \mathrm{l}$ \\
\hline
\end{tabular}

Table (2): results of CFT in sera of chickens.

\begin{tabular}{ccccc}
\hline Total No. of chicken's sera & \multicolumn{3}{c}{ 68 randomly serum samples } \\
\hline \multirow{2}{*}{ Results of CFT } & Positive & \multicolumn{3}{c}{ Negative } \\
& No. & $\%$ & No. & $\%$ \\
& 20 & 29.91 & 48 & 70.09 \\
\hline
\end{tabular}

CFT titer ranged from $1 / 8-1 / 128$

\section{Materials and Methods}

Chickens. This study was preformed on randomly collected total number of 68 chickens located in Ras Sedr station (Desert Research Center, Egypt). The history and clinical examination of poultry in farm were recorded.

Samples. Blood samples were collected from chickens and sera were used in PCR and serological tests respectively.

Antisera. Reference antisera for Chlamydia; Chlamydia psittaci, ( Seiken, Denka Seiken Co., LTd, Tokyo, Japan) was used in CFT for detection of chlamydia bodies in the suspected materials.

Reference Chlamydia antigen. It was obtained from Denka Seiken Co., LTd, Tokyo, Japan. It was used for serological detection of antibodies.

Complement. Freeze dried preparation of preserved guinea pig serum (Welcome) was used in complement fixation technique.

Polymerase Chain Reaction (PCR). Ten randomly collected blood samples from serologically positive cases were subjected to PCR.

DNA extraction. The genomic DNA was extracted from samples using Invisorb Spin Blood Mini Kit (Invitek GmbH Gesellschaft Biotechnik-Robert-Rossle-Berlin).

PCR amplification of chlamydial DNA. PCR amplification of chlamydial DNA was performed on DNA extracted from serum samples using oligonucleotide primers Chla. 2 AF:5-GCTTTTCTAATTTACACC-3 and Chla. 2 Br: 5- ATAGGGTTGAGACTATCCACT - 3 according to (Sykes et al., 1997). $2 \mu \mathrm{l}$ of template added to each tube containing master mix (Table.1). Distilled water was used as negative control while pure DNA of Chlamydia psittaci was used as positive control. The reaction was subsequently at $95^{\circ} \mathrm{C}$ for $10 \mathrm{~min}$. then for 40 cycles at $95^{\circ} \mathrm{C}$ for 30 seconds, $50^{\circ} \mathrm{C}$ for 30 seconds, and $72^{\circ} \mathrm{C}$ for 45 seconds, followed by an additional elongation at $72^{\circ} \mathrm{C}$ for 10 minutes. Reaction product was visualized by ethidium bromide staining under UV transillumination after electrophoresis on $1.5 \%$ agarose gel.

\section{Results}

History of farms and clinical manifestation. Ras Sedr Research Station contains poultry as well as small ruminant. Some pregnant ewes and pregnant goats aborted at late stage of pregnancy and the chlamydial infection was proven by serological test and PCR. Detection of antibodies against chlamydia and positive PCR results for Chlamydophila abortus (Chlamydia psittaci) on aborted foeti were also achieved during the present investigation. To investigate the source of infection, seroprevalence and PCR on chicken sera revealed positive results for Chlamydophila psittaci (Chlamydia psittaci) although these chickens did not show any symptoms of chlamydial infections.

Serological results. Results of serological studies were demonstrated in Table 2.

Results of Polymerase Chain Reaction (PCR). Ten randomly collected samples of blood of chickens from serologically positive cases for Chlamydophila psittaci revealed positive results by using PCR at $119 \mathrm{bp}$. The positive control showed the excepted amplification product 


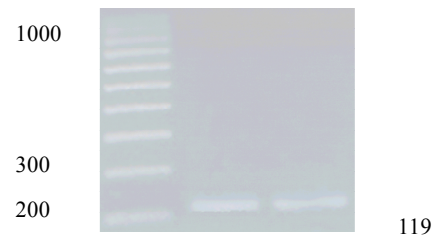

Fig. (1): PCR of Chlamydophila psittaci (Chlamydia psittaci) DNA was extracted from blood of chicken. PCR products were separated on $1.5 \%$ agarose gel and stained with ethidium bromide lane1, 100 bp ladder marker ; lane 2, positive control (C. psittaci); lane 3, specific $C$. psittaci PCR product (119 bp detected).

(119bp) as shown (Fig.1).

\section{Discussion}

Infections with Chlamydophila psittaci are quite often found in commercial poultry (chicken, turkeys, ducks, geese and doves). The spread of the causative organisms from poultry to animal and human beings may happen (Heike, 2004).

Serological study by using complement fixation test is the most commonly used for detection of antibodies against Chlamydophila psittaci. Positive results were recorded in $29.91 \%$ of chickens' sera. The detection of Chlamydophila psittaci antibodies in the investigated samples by CFT is similar to that obtained by (Vlahovic et al., 1998; Pavlak et al., 2000).

CFT was found to be more sensitive than agar gel precipitation test and elementary body agglutination with $21,16,17.5$ and $12.5 \%$, respectively in seroprevalence of chlamydiosis (Paul et al., 2002).

Although, CFT is commonly used, but is of quite low sensitivity (Schmeer 1983; Gerbermann and JanecZek, 1991; Salinas et al., 1993; Bendheim et al.,1998; Prunkner-Radovic et al., 2005). On the other hand, ELISA in comparison with CFT was found to be more accurate and highly sensitive (Salinas et al., 1993).

In this work because CFT is complicated by false positive due to cross reaction between Chlamydophila species (Longbotton et al., 2001) so using molecular biology for diagnosis of Chlamydophila psittaci is very recommended.

Regarding the advanced techniques for the detection of Chlamydophila psittaci, ten randomly collected blood samples of chickens serologically positive by CFT were subjected to PCR using both " $2 \mathrm{~A}$ " and " $2 \mathrm{~B}$ " primers which are specific for identification of Chlamydophila psittaci DNA. All the examined blood samples showed the expected amplification product specific for Chlamydophila psittaci (119 bp). This finding was in parallel line with Heike, (2004) and Dove et al. (2005) who reported that PCR is a specific, sensitive and rapid test for the detection of Chlamydophila psittaci in birds.

In this study the chickens were asymptomatically carriers for Chlamydophila psittaci in their body excretions as faeces or respiratory discharges. It is concluded that avoidance of breeding of chickens with other animal species in the same yard.

\section{References}

Bendheim, M.; Naveh, A. and Keren, E. (1998): Antibody testing for Chlamydia psittaci using a rapid ELISA-Kit. Proceeding of International Virtual Conference in Veterinary Medicine: Diseases of psittacine Birds. Georgia, USA.

Chahota, R.; Katoch, R. C. and Joshi, V. B. (1997): Seroprevalence of Chlamydia psittaci in domestic poultry and wild birds. Ind. J. Poul. Sci., 32: 67-71.

Dottori, M.; Nobili, L.; Coneva, F. D.; Paterlin, F. and Perini, S. (2000): Evaluation of two different serological methods for determining the presence of antibodies to Chlamydia psittaci in the sera of pigeons (Columba livia). Selezione Veterinaria, 6: 381-385.

Dove, A.; Dov, P.; Kese, D.; Vlahovic, K.; Pavlak, M. and Zorman-RoJs, O. (2005): Long-term study of Chlamydophilosis in Slovenia. Vet. Res. Comm., 29 (suppl.1): 23-36.

Duan, Y. J.; Souriau, A.; Mahe, A. M.; Trap, D.; Anderson, A. A. and Rodolakis, A. (1999): Serotyping of Chlamydial clinical isolates from birds with monoclonal antibodies. Avian Dis., 43: 22-28.

Eugster, A. K. (1980): Hand book series in zoonoses. Section A. (CRC press. Boca Roton).

Everett, K. D.; Bush, R. M. and Anderson, A. A. (1999): Emended description of the order chlamydiales. Int. J. Sys. Bacteriol., 49: 415-440.

Gerbermann, H. and Janeczet, F. (1991): Chlamydiose bei vogeln: Gegenwartige situation und Alternative der diagnose and Bekanfung. Der prakische tierarzt-Zeitschrift fur Forts Schrittliche Veterinar Medezin, 6: 1-8.

Greguric, J.; Dobec, M. and Vueemilo, M. (1989): Chlamydiosis/ornithosis of the domestic pigeon in the city area of Zagreb. Vetrinarski Glasnik, 43: 619-623.

Grimes, J. E. (1984): Serological and microbiological detection of Chlamydia psittaci infections in psittacine birds. Avian/Exotic practice 1: 6-12.

Grimes, J. E. (1985): Enigmatic psittacine Chlamydiosis Results of serotesting and isolation attempts, 1978 through 1983 and considerations for the future. J. Am. Vet. Med. Assoc., 186: 1075-1079.

Grimes, J. E. and Arizmendi, F. (1990): Serology, culture and antigen capture in the diagnosis of chlamydial infection in psittacine birds. Proc. Annual Conference Association Avian Veterinarians. Phoenix, pp. 272-278.

Guscetti, F.; Hoop, R.; Schiller, I.; Corboz, L.; Sydler, T. and Pospichil, A. (2000): Experimental enteric infection of genotobiotic piglets with a Chlamydia psittaci strain of avian origin. J. Vet. Med.B, 47 (8): 561-572.

Heike, N. (2004): Detection of Chlamydophila psittaci in different areas of two chicken and two turkey abattoirs by isolation in Buffalo Green Monkey Kidney cell cultures plus subsequent direct immunofluorescence and by 
polymerase chain reaction followed by restriction enzyme analysis. Inaugural-Dissertation Zur Erlangungdes Doktorgrades bein Fachbereich veterinarmedizin der JustusLiebig-Universtat GieBen.

Kaleta, E. F. and Today, E. M. A. (2003): Avian host range of Chlamydophila spp. based on isolation, antigens detection and serology. Avian Pathol., 32: 435-462.

Kemf, I.; Trap, D.; Mahe, A. M.; Hafez, M.; Kermorgant, P. and Colin P. (2000): Turkey chlamydiosis in Brittany: serological results. Sci. Tech. Avic., 33: 29-32.

Ketz, C. J. and Carpenter, J. W. (1999): What is your diagnosis ? J. Avian Med. Surg., 13: 218-222.

Longbotton, D.; Psarrou, E.; Livingstone, M. and Vreton, E. (2001): Diagnosis of ovine enzootic abortion using an indirect ELISA (romp g1Bi ELISA) based on a recombinant protein fragment of the polymorphic outer membrane protein PoMpg1B of Chlamydophila abortus. FEMS-Microbiol. Lett., 195 (2): 157-161.

Messmer, T. O.; Sketton S. K.; Moroney J. F.; Daugharty H. and Fields B. S. (1997): Application of a nested multiplex PCR to Psittacosis outbreaks. J. Clin. Microbiol., 35 (8): 2043-2046.

Paul, R.; Katoch, R. C.; Rajesh, Chahota.; ArvindMahajan.; Chahota, R. and Mahajan, A. (2002): Seroprevalence of chlamydiosis among cows and buffaloes in Himachal pradesh. Ind. J. Anim. Sci., (72) 6: 434-435.

Pavlak, M.; Vlahovic, K.; Greguric, J.; Zupancic, Z.; Jercic, J. and Bozikov, J. (2000): An epidemiologic study of chlamydia sp. in free living pigeons (Columba livia var. domestica). Zeitschrift Jagdwissen-Schaft, 46: 84-95.

Prunkner-Radovic, E.; Horvatek, D.; Gottstein, Z.; Grozdanic, I. And Mazija, H. (2005): Epidemiological investigation of Chlamydophila psittaci in pigeons and free living birds in Croatia. Vet. Res. Comm., 29 (suppl.1): 17-
21.

Salinas, J.; Caro, M. R. and Cuello, F. (1993): Comparison of different serological methods for the determination of antibodies to Chlamydia psittaci in pigeon ser. J. Vet. Med., B40: 239-244.

Schmeer, N. (1983): Enzyme immuno assay for detection of IgG and IgM antibodies against Chlamydia psittaci in the pigeons. Zentralblatt for Veterinar Medizin Reieh B., 30: 356-370

Sykes, J. E.; Studdert, V. P. and Anderson, G. (1997): Comparison of Chlamydia psittaci from cats with upper respiratory tract disease by polymerase chain reaction analysis of the ompA gene. Vet. Rec., 140: 310-313.

Travnicek, M.; Cislakova, L. and Misko, J. (2000): Presence of antibodies to Chlamydia psittaci in farm managed pheasants (Phasinaus colchicus) and pigeons (Columba livia). Veterinarni Medicina, (45) 3: 149-151.

Tully, T.N.Jr. (1991): Evaluation of diagnostic procedures for Chlamydia psittaci. Proc. Ann. Conf. Assoc. Avian Vet. Chicago, pp. 137-140.

Vanrompay, D.; De Meurichy, W.; Ducatelle, R. and Haesebrouck, F. (1994): Pneumonia in Moorish tortoises (Testudo graeca) associated with avian serovar A Chlamydia psittaci. Vet. Rec., 135: 284-285.

Vlachovic, K.; Zupancic, Z.; Greguric, J. and Pavlak, M. (1998): Zur zaverlassigkeit diagnosticher vaerfahren beim Nachweis von Infektionen mit Chlamydophila spp. bei vogeIn Reliability of diagnostic methods in proving infections of Chlamydia spp in birds. Zeitschrift fur Jagdwissenschaft, 44: 133-139.

Wilcke, B. W.; Jr., Newcomer, C.E.; Anver, M.R.; Simmons, J. L. and Nace, G. W. (1983): Isolation of Chlamydia psittaci from naturally infected African clawed frogs (xeopus laevis). Infec. Imm. 41: 789-794.

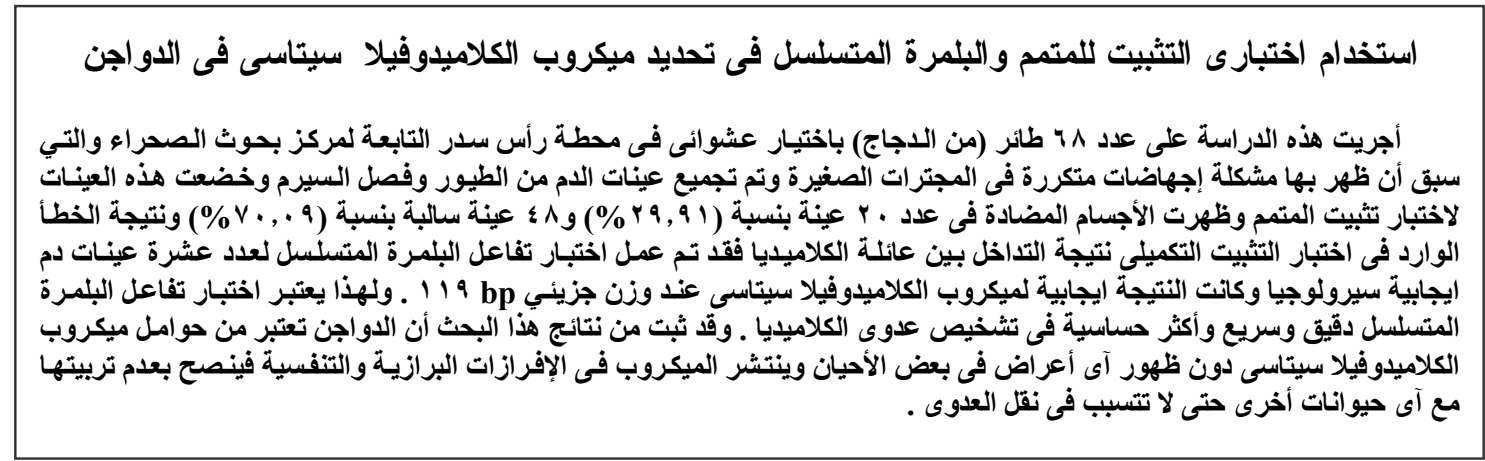

